Metallophysics and Advanced Technologies

Металофіз. новітні технол.

Metallofiz. Noveishie Tekhnol.

2021 , vol. 43 , No. 10 , pp. $1365-1375$

https://doi.org/10.15407/mfint.43.10.1365

Reprints available directly from the publisher
(C) 2021 G. V. Kurdyumov Institute for Metal Physics, National Academy of Sciences of Ukraine Published by license under the G. V. Kurdyumov Institute for Metal PhysicsN.A.S. of Ukraine Publishers imprint. Printed in Ukraine.

PACS numbers: 62.20.Qp, 64.60.My, 68.35.Md, 73.30.+y, 73.40.Cg, 81.40.Pq

\title{
High-Entropy ZrTiCrNiCu Coating
}

\author{
S. A. Guchenko, V. M. Yurov, V. I. Goncharenko", and V. S. Oleshko*
}

E. A. Buketov Karaganda State University, 28 Universitetskaya Str., 100026 Karaganda, Kazakhstan

"Moscow Aviation Institute (National Research University), 4 Volokolamskoe Shosse, RU-125993 Moscow, Russia

A high-entropy alloy $\mathrm{ZrTiCrNiCu}$ and coating are synthesized by mechanical alloying. The microhardness of the $\mathrm{ZrTiCrNiCu}$ coating is not inferior and in most cases exceeds the hardness of highly entropic equiatomic alloys. The wear resistance of the $\mathrm{ZrTiCrNiCu}$ coating is $3 \cdot 10^{-4} \mathrm{~g} / \mathrm{min}$, which also meets the special steels for wear resistance. A high-entropy coating has a low coefficient of friction. They turn out to be anti-friction, which, in all likelihood, leads to energy savings. The surface energy, contact potential difference, and electron work function for high entropy coatings are first determined in the work.

Key words: high-entropy alloy, plasma coating, microhardness, friction, wear resistance.

Високоентропійний стоп $\mathrm{ZrTiCrNiCu}$ та покриття синтезують механічним легуванням. Мікротвердість покриття $\mathrm{ZrTiCrNiCu}$ не поступається і в більшості випадків перевищує твердість високоентропійних еквіатомних стопів. Зносостійкість покриття $\mathrm{ZrTiCrNiCu}$ становить $3 \cdot 10^{-4}$ г/хв, що також відповідає спеціальним сталям для зносостійкості. Покриття з високою ентропією мають низький коефіцієнт тертя. Вони виявляються антифрикційними, що, ймовірно, призводить до економії енергії. Вперше в роботі визначено поверхневу енергію, контактну різницю потенціалів та роботу виходу електрона для високоентропійних покриттів.

Ключові слова: високоентропійний стоп, плазмове покриття, мікротвер-

Corresponding author: Sergey Alexeevich Guchenko

E-mail: guchen@mail.ru

Citation: S. A. Guchenko, V. M. Yurov, V. I. Goncharenko, and V. S. Oleshko, High-Entropy ZrTiCrNiCu Coating, Metallofiz. Noveishie Tekhnol., 43, No. 10: 1365-1375 (2021), DOI: 10.15407/mfint.43.10.1365. 
дість, тертя, зносостійкість.

(Received March 6, 2020; in final version, July 22, 2021)

\section{INTRODUCTION}

According to the authors of [1], a distinctive feature of high-entropy alloys (HEAs) from traditional alloys is that these alloys have high entropy of mixing, which affects the formation of structures based on solid solutions. Just over 15 years have passed since the discovery of high-entropy alloys (2004). The first review is performed as a complete material science cycle 'production-structure-properties' for a new class of vacuum-plasma coatings - nitrides of multi-element high entropy metal alloys in [2].

A current state analysis is made for the production of such coatings, their morphology, elemental and phase compositions, structure, substructure, stress state and functional properties depending on the main formation parameters: substrate temperature during deposition, magnitude of the bias potential supplied to the substrate, and the composition of the gas atmosphere. Then many articles appeared on the synthesis and study of various high-entropy alloys [3-9].

The latest review on HEAs is made in [10]. An analysis of more than 200 obtained high entropy alloys (HEA) allowed to establish the relationship between the electron concentration, phase composition, lattice parameter and the properties of solid solutions based on b.c.c., f.c.c. lattice.

The basic conditions for the appearance of high-entropy chemical compounds - the Laves phase, $\sigma$ - and $\mu$-phases, are revealed. For the formation of a $100 \%$ high-entropy $\sigma$-phase, a necessary condition is that all the elements that make up the high-entropy alloys must form the $\sigma$-phase in two-component alloys in a different combination, and the electronic concentration of the alloy should be in the range of $6.7-$ 7.3 electron/atom.

For the formation of a $100 \%$ high-entropy phase of Laves the following conditions are required: the total negative enthalpy of alloy mixing at the level of $-7 \mathrm{~kJ} / \mathrm{mol}$ and below; pairs with an atomic difference of more than $12 \%$; the presence in the alloy of two elements with a mixing enthalpy of less than $-30 \mathrm{~kJ} / \mathrm{mol}$, the average electron concentration should be in the range of 6-7 electron/atom. It is shown that the ratio of the lattice parameters of solid-state HEA, determined in the experiment, to the lattice parameter of the most refractory metal of the HEA determine the magnitude of the elastic modulus.

In this article, a high-entropy alloy $\mathrm{ZrTiCrNiCu}$ has been synthesized and studied for the first time, which has unique mechanical properties: the hardness is $2-3$ times higher than that of traditional 
stainless steels, and the friction coefficient has a small value (0.04) at the level of layered materials.

\section{EXPERIMENTAL/THEORETICAL DETAILS}

\subsection{Method for the Synthesis of ZrTiCrNiCu Alloy and Coating}

The following article is taken as a basis [11]. For the preparation of the $\mathrm{ZrTiCrNiCu}$ target, micropowders of the corresponding metals are taken and mixed in equiatomic proportions. Then, the prepared powder mixture is placed in a grinding bowl of a planetary ball mill made of tungsten carbide and grinding bodies are added. Grinding bodies are balls with a diameter of $5-10 \mathrm{~mm}$, also made of tungsten carbide, the mass of which is equal to 10 masses of the powder mixture.

Then the grinding bowl is filled with gasoline galosh, the lid is tightly closed and the planetary ball mill is turned on (rotation speed is 500 rpm, operation time 5 hours). The resulting homogenized composition is then dried in a vacuum and pressed with a mold into a flat disk with a diameter of $100 \mathrm{~mm}$ and a thickness of $5 \mathrm{~mm}$. Next, the disk is placed in a vacuum thermo-furnace and sintered in it for 3 hours. Further, the fabricated $\mathrm{ZrTiCrNiCu}$ target (Fig. 1) is used for applying a magnetron coating on the NNV-6.6I1 installation.

Coating is carried out on prepared substrates made of AISI-201 steel (hexagons with a side length of $22 \mathrm{~mm}$ and a thickness of $5 \mathrm{~mm}$ ). The vacuum chamber is evacuated to a pressure of $0.003 \mathrm{~Pa}$, then a plasma source with a hot cathode (PSWHC) is turned on, argon or nitrogen is injected to a pressure of $1 \mathrm{~Pa}$, a negative bias potential of $1000 \mathrm{~V}$ is ap-

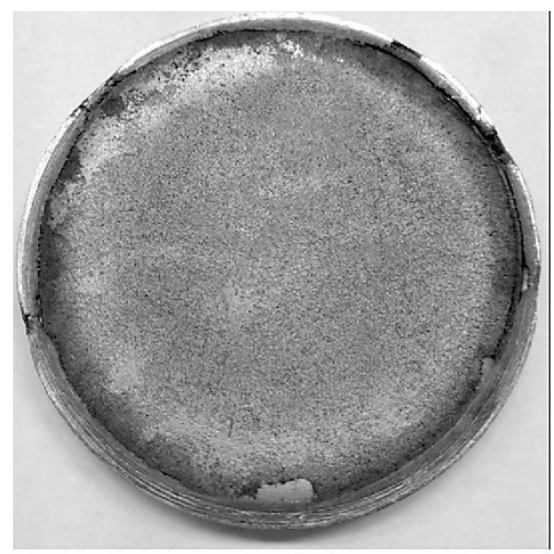

$a$

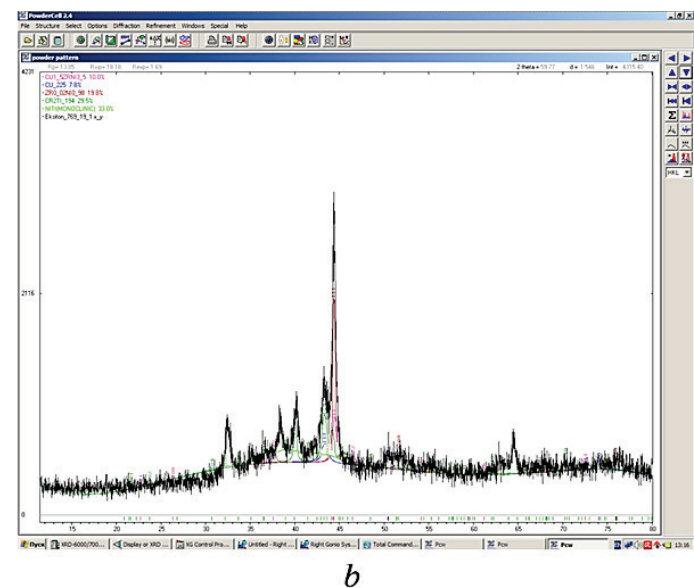

Fig. 1. ZrTiCrNiCu target for a magnetron (a), the plot of the ZrTiCrNiCu diffraction pattern $(b)$. 
TABLE 1. The phase composition of the coating.

\begin{tabular}{c|ccc}
\hline Sample & Detected phases & The content of phases, at.\% & Lattice parameters, $\AA$ \\
\hline & $\mathrm{Cu}_{1,5} \mathrm{ZrNi}_{3.5}$ & 10 & $a=6.7671$ \\
& $\mathrm{Cu}$ & 7.8 & $a=3.6178$ \\
& $\mathrm{Zr}_{0.02} \mathrm{Ni}_{0.98}$ & 19.8 & $a=3.5406$ \\
$\mathrm{ZrTiCrNiCu}$ & $\mathrm{Cr}_{2} \mathrm{Ti}$ & 29.5 & $a=4.9076$ \\
& & & $c=15.9700$ \\
& & & $a$ \\
& $\mathrm{NiTi}$ & & $b=4.6192$ \\
& & & $c=4.1824$ \\
& & & \\
& & & \\
& & & \\
& &
\end{tabular}

plied to the substrate, and the substrate surface is cleaned and heated for 10 minutes. After that, the argon pressure is lowered to $0.1 \mathrm{~Pa}$ and the magnetron is switched on. The bias potential on the substrate is reduced to $150 \mathrm{~V}$, the magnetron current is kept constant at $3 \mathrm{~A}$. The substrate is located in the chamber at a distance of $15 \mathrm{~cm}$, the spraying time is 1 hour.

\subsection{Diffractometry of $\mathrm{ZrTiCrNiCu}$ Coatings}

The phase composition and structural parameters of the samples are studied using an XRD-6000 diffractometer using $\mathrm{Cu} K_{\alpha}$ radiation.

The phase composition analysis is carried out using PDF 4 + databases, as well as the POWDER CELL 2.4 full-profile analysis program. Table 1 and in Fig. 1, $b$ show data on the studied samples.

\subsection{Electron Microscopic Examination of $\mathrm{ZrTiCrNiCu}$ Coatings}

Electron microscopy is carried out using a TESCAN MIRA 3 scanning electron microscope. Figure 2 shows the XPS of coatings, and Table 2 shows the chemical composition.

From Figures 1, 2 and Tables 1, 2 it follows that when the highentropy alloy $\mathrm{ZrTiCrNiCu}$ is sprayed at a pressure of up to $1 \mathrm{~Pa}$, no nitrides are formed. The coating thickness is $7-10$ microns.

\subsection{Microhardness of $\mathrm{ZrTiCrNiCu}$ Coatings}

The microhardness of the coatings is studied on an HVS-1000A microhardness tester. The microhardness measurements of $\mathrm{ZrTiCrNiCu}$ 

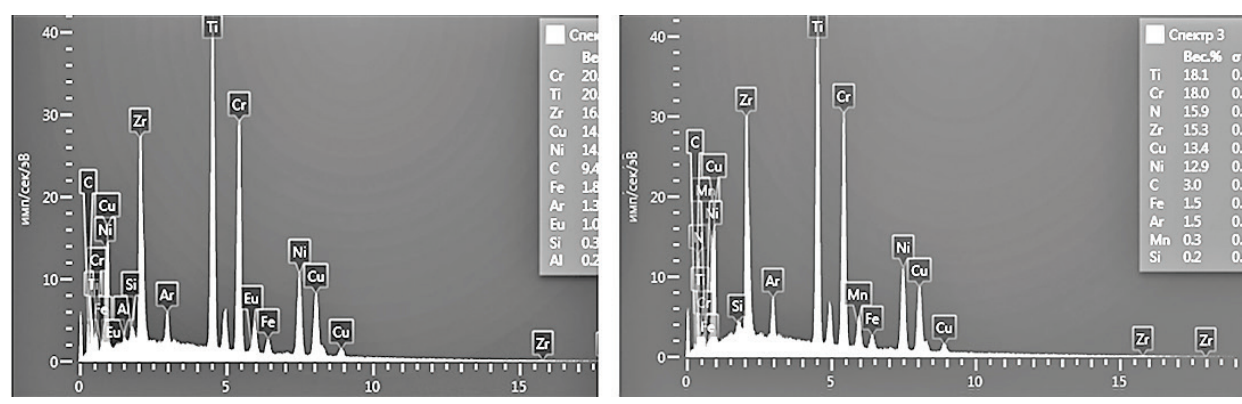

Fig. 2. XPS of $\mathrm{ZrTiCrNiCu}$ in argon at 2 points.

TABLE 2. Quantitative chemical composition of $\mathrm{ZrTiCrNiCu,} \mathrm{\%} \mathrm{.}$

\begin{tabular}{c|ccccc}
\hline Element & $\mathrm{Zr}$ & $\mathrm{Ti}$ & $\mathrm{Cr}$ & $\mathrm{Ni}$ & $\mathrm{Cu}$ \\
Nominal & 20 & 20 & 20 & 20 & 20 \\
In argon & 23.2 & 21.2 & 19.9 & 17.1 & 6.8 \\
In nitrogen & 22.8 & 20.8 & 19.7 & 16.9 & 7.0 \\
\hline
\end{tabular}

coatings are given in Table 3. The microhardness of $\mathrm{ZrTiCrNiCu}$ coatings in argon and nitrogen is almost unchanged. This means that nitrogen does not form part of the coating.

Compare the data of Table 3 with the data of high-entropy alloys (Table 4). It turned out that these cast materials, along with the characteristics typical of metal alloys, had unique and unusual properties inherent, for example, to cermets: high hardness and resistance to softening at high temperatures, dispersion hardening, a positive temperature coefficient of hardening, and a high level of strength characteristics at elevated temperatures, attractive wear resistance, corrosion resistance and a number of other properties.

The microhardness of our $\mathrm{ZrTiCrNiCu}$ coating is not inferior to highly entropic equiatomic alloys.

\subsection{Tribological Features of $\mathrm{ZrTiCrNiCu}$ Coatings}

Tribological studies are carried out on the setup described in [13]. $\mathrm{ZrTiCrNiCu}$ is sprayed on a stationary sample for an hour with a refer-

TABLE 3. Microhardness of $\mathrm{ZrTiCrNiCu}$ coating in argon and nitrogen.

\begin{tabular}{c|cccccccc}
\hline Microhardness & 1 & 2 & 3 & 4 & 5 & 6 & 7 & Average \\
$H V$, argon & 839 & 909 & 864 & 842 & 967 & 753 & 821 & 890 \\
$H V$, nitrogen & 897 & 899 & 899 & 863 & 879 & 887 & 966 & 890 \\
\hline
\end{tabular}


TABLE 4. Microhardness of high entropy alloys [12].

\begin{tabular}{c|c|c}
\hline Alloys & $\begin{array}{c}\text { Initial hardness cast } \\
\text { alloys, } H V\end{array}$ & $\begin{array}{c}\text { Alloy hardness after } \\
\text { annealing, } H V\end{array}$ \\
\hline CuTiVFeNiZr & 590 & 600 \\
AlTiVFeNiZr & 800 & 790 \\
MoTiVFeNiZr & 740 & 760 \\
CuTiVFeNiZrCo & 630 & 620 \\
AlTiVFeNiZrCo & 790 & 800 \\
MoTiVFeNiZrCo & 790 & 790 \\
CuTiVFeNiZrCoCr & 680 & 680 \\
AlTiVFeNiZrCoCr & 780 & 890 \\
MoTiVFeNiZrCoCr & 850 & 155 \\
316 Stainless steel & 189 & 362 \\
17-4 PH Stainless steel & 410 & 280 \\
Hastelloy C (based Ni-Mo-Fe) & 236 & 494 \\
Stellite 6 (based Co-Cr) & 413 & 890 \\
Microhardness of our & 890 & \\
ZrTiCrNiCu coating & &
\end{tabular}

ence voltage of 150 and 250 volts in a constant power mode of $1.5 \mathrm{~kW}$ (Table 5).

High entropy ZrTiCrNiCu coatings turn out to be anti-friction, which in all probability leads to energy savings.

\subsection{Work Function, Surface Energy and Properties of ZrTiCrNiCu Coatings}

The measurement complex of the contact potential difference developed by the authors of [14] is shown in Fig. 3. The sensor housing is designed in the SolidWorks program and printed on a Picaso 3D Designer $3 \mathrm{D}$ printer.

The sensor housing is designed to provide a gap between the measuring electrode and the capacitor of $0.5 \mathrm{~mm}$ at rest. The advantages of the capacitor method of the contact potential difference are:

- the capacitor can be manufactured with high accuracy;

TABLE 5. Friction coefficients for steel and aluminium.

\begin{tabular}{c|c|c|c|c}
\hline \multirow{2}{*}{ Coating } & \multicolumn{2}{|c|}{ For steel } & \multicolumn{2}{c}{ For aluminium } \\
\cline { 2 - 5 } & $\begin{array}{c}\text { Coefficient of } \\
\text { friction }\end{array}$ & Error & $\begin{array}{c}\text { Coefficient of } \\
\text { friction }\end{array}$ & Error \\
\hline ZrTiCrNiCu argon & 0.081 & 0.006 & 0.066 & 0.002 \\
ZrTiCrNiCu nitrogen & 0.097 & 0.001 & 0.077 & 0.004 \\
\hline
\end{tabular}




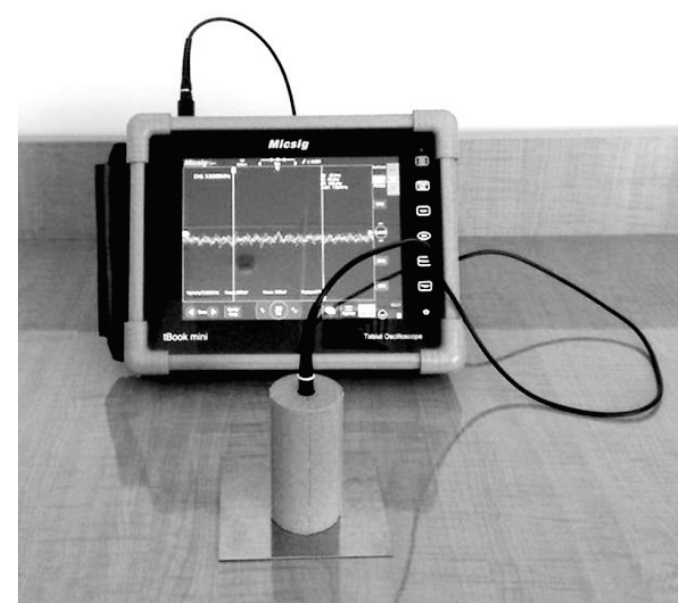

Fig. 3. Complex for measuring the contact potential difference of metal parts.

- the capacitor has low losses (the passage of electric current through capacitive resistance is not accompanied by heat loss) and a high efficiency;

- the shape of the capacitor type sensor can be adapted to various surface shapes of the sample.

The indicated design features of the sensor allow reliable measurements of the contact potential difference of metals (Table 6).

\section{RESULTS AND DISCUSSION}

The high-entropy alloy $\mathrm{ZrTiCrNiCu}$ made by mechanical alloying followed by calcination at a temperature of $1100^{\circ} \mathrm{C}$ shows a very good property, which does not change with time. This alloy is obtained from pure metal spherical micropowders with a diameter of not more than 20 microns. This size satisfies the mechanical alloying method re-

TABLE 6. Surface energy, contact potential difference (CPD), and electron work function for the alloy and its composition.

\begin{tabular}{c|c|c|c|c}
\hline Coating & $T_{m}, \mathrm{~K}$ & $\sigma, \mathrm{J} / \mathrm{m}^{2}$ & $\mathrm{CPD}, \mathrm{mV}$ & $\varphi, \mathrm{eV}$ \\
\hline $\mathrm{ZrTiCrNiCu}$ & 1642 & 1.149 & 271 & 4.73 \\
$\mathrm{Ni}$ & 1726 & 1.208 & - & $4.91-5.01$ \\
$\mathrm{Cr}$ & 2130 & 1.491 & 187 & 4.60 \\
$\mathrm{Ti}$ & 1943 & 1.360 & - & 4.33 \\
$\mathrm{Zr}$ & 2125 & 1.488 & - & 4.12 \\
$\mathrm{Cu}$ & 1336 & 0.935 & 374 & 4.36 \\
\hline
\end{tabular}


quirements.

In the Table 2 shows the quantitative chemical composition of $\mathrm{ZrTiCrNiCu}$, \%, which proves that we have a high-entropy coating. In the Table 1 shows the phase composition of the coating. We will discuss this composition.

The first is $\mathrm{Cu}_{1.5} \mathrm{ZrNi}_{3.5}$ with a phase content of 10 at. $\%$ and with a lattice constant equal to $a=6.7671 \AA$. According to $[15,16]$, the structure of $\mathrm{Cu}_{1.5} \mathrm{ZrNi}_{3.5}$ is $\mathrm{B} 2$-a high-temperature austenitic phase ordered by the $\mathrm{CsCl}$ type (Pm3m-f.c.c.).

In second place is $\mathrm{Cu}$ with a phase content of 7.8 at.\% and lattice constant $a=3.6178 \AA$. The unit cell of copper is f.c.c.

Third place is $\mathrm{Zr}_{0.02} \mathrm{Ni}_{0.98}$ with a phase content of 19.8 at. $\%$ and lattice constant $a=3.3406 \AA$. According to X-ray spectral analysis, the main component of the eutectic is the combination of nickel and zirconium. The eutectic component is identified as a $\mathrm{ZrNi}$ intermetallic compound with an f.c.c. lattice corresponding to the space group $F 43 m$ (sphalerite type).

Fourth place is $\mathrm{Cr}_{2} \mathrm{Ti}$ with a phase content of 29.5 at. $\%$ and lattice constant $a=4.9076 \AA$ and $c=15.9700 \AA$. Near the $\mathrm{TiCr}_{2}$ composition, intermediate phases with the Laves structure are formed [17].

In fifth place is NiTi with a phase content of 33 at.\% and the lattice constant $a=2.8007 \AA, b=4.6192 \AA, c=4.1824 \AA, \beta=97.5793$. According to [18], the results of neutron diffraction studies of quenched alloys in the initial austenitic and martensitic states show that the $\mathrm{Ti}_{49.5} \mathrm{Ni}_{50.5}$ alloy is in the austenitic state at room temperature. The parameter of its crystal lattice B2 $(a)$ and the degree of long-range atomic order $(\eta)$ turned out to be $a=0.30125 \mathrm{~nm} ; \eta=1.00 \pm 0.05$. In contrast, the $\mathrm{Ti}_{50.5} \mathrm{Ni}_{49.5}$ alloy at room temperature is in the $\mathrm{B} 19^{\prime}$ martensite state, which unambiguously follows from the interpretation of the neutron diffraction pattern and allows one to determine its parameters: $a=0.2903, b=0.4112, c=0.4636 \mathrm{~nm}, \beta=97.25$. The NiTi observed by us turns out to be martensite with the B19' structure.

Thus, of the five high entropy $\mathrm{ZrTiCrNiCu}$ coatings, three have an MCC structure, $\mathrm{TiCr}_{2}$ gives the Laves phase, and NiTi gives martensite with the B19' structure.

Microhardness combined with a low coefficient of friction leads to good wear resistance of the $\mathrm{ZrTiCrNiCu}$ coating. The application of such a coating to parts of locomotives of rolling stock showed an increase in service life by 4 times. The coatings are made on steel parts DTRKZ4AC00446.

As for the contact potential difference and the electron work function for the $\mathrm{ZrTiCrNiCu}$ alloy, we can conclude that this alloy is not inferior to copper alloys in their electrical characteristics.

The very good performance of the coatings from the $\mathrm{ZrTiCrNiCu}$ target is most likely due to titanium and zirconium nickelides. These 
compounds have the property of shape memory [19]. One of the most relevant areas of application of these materials is the so-called active devices (devices that perform mechanical work under the influence of heat, for example, drives). An alloy with a shape memory effect when operating in such devices is subjected to various thermomechanical influences, such as dynamic loading, a single or multiple temperature change through a full or incomplete temperature range of a reversible martensitic transformation.

We emphasize once again the uniqueness of the coating we have obtained. In [20], we obtained the formula:

$$
k=C T \frac{\sigma S}{\tau G^{0}} \Delta t \bar{n},
$$

Equation (1) describes the friction coefficient $k$ proportional to the time of motion during friction $\Delta t$, the work of friction forces $A=\sigma S$, the electron concentration $n$, surface energy $\sigma$, contact area $S$ and is inversely proportional to the relaxation time $\tau$ and Gibbs energy $G^{0}$ of the thermostat, $C=$ const.

For high-entropy coatings $G^{0}=H-T S+P V \rightarrow S \sim 2 R$ and the friction coefficient should decrease. Its decrease is also associated with the formation of nanostructures and the dependence of the surface energy $\sigma$ according to A. I. Rusanov: $\sigma=K r \rightarrow 0$ at $r \rightarrow 0$. Surface energy $\sigma$ linearly depends on the hardness of the alloy: $\sigma=\alpha \mu, \alpha=$ const. Thus, equation (1) shows that the coefficient of friction of the coating decreases with the use of a high-entropy alloy and with a decrease in the surface energy of the coating.

\section{CONCLUSION}

Thus, of the five high entropy $\mathrm{ZrTiCrNiCu}$ coatings, three have an MCC structure, $\mathrm{TiCr}_{2}$ gives the Laves phase, and NiTi gives martensite with the B19' structure.

The proposed high-entropy coating $\mathrm{ZrTiCrNiCu}$ on parts of locomotives of rolling stock is based on its high hardness $(890 \mathrm{MPa})$ and low friction coefficient $(\mathbf{0 . 0 4})$, which leads to an increase in wear resistance and increases the service life of these parts by 3-4 times. High-entropy coatings due to the small thickness ( 7-10 microns) of parts of enterprises can be applied again after abrasive wear. Highentropy coatings have unique properties due to the formation of a nanostructure in the surface layer. We have shown this theoretically [20], considering them by the method of quantum thermodynamics of irreversible processes, and experimentally, considering them by the methods of electron microscopy, microhardness tester and automatically measuring the friction coefficients. Equation (1) describes the 
friction coefficient $k$ proportional to the time of motion during friction $\Delta t$, the work of friction forces $A=\sigma S$, the electron concentration $n$, surface energy $\sigma$, contact area $S$ and is inversely proportional to the relaxation time $\tau$ and Gibbs energy $G^{0}$ of the thermostat.

For high-entropy coatings $G^{0}=H-T S+P V \rightarrow S \sim 2 R$ and the friction coefficient should decrease. Its decrease is also associated with the formation of nanostructures and the dependence of the surface energy $\sigma$ according to A. I. Rusanov: $\sigma=K r \rightarrow 0$ at $r \rightarrow 0$.

\section{ACKNOWLEDGEMENT}

The work is carried out under the program of the Ministry of Education and Science of the Republic of Kazakhstan Grants No.0118RK000063 and No. F.0780.

\section{REFERENCES}

1. J. W. Yeh, Y. L. Chen, and S. J. Lin, Mater. Sci. Forum, 560: 1 (2007).

2. N. A. Azarenkov, O. V. Sobol, and V. M. Beresnev, Metallofiz. Noveishie Tekhnol., 35, No. 8: 1061 (2013) (in Russian).

3. S. A. Firstov, V. F. Gorban, N. A. Krapivka, and E. P. Pechkovsky, Tambov University Reports. Series Natural and Technical Sciences, 18, No. 4: 1938 (2013) (in Russian).

4. S. A. Firstov, V. F. Gorban, A. O. Andreev, and N. A. Krapivka, Nauka Innov., 9, No. 5: 32 (2013) (in Russian).

5. A. D. Pogrebnyak, A. A. Bagdasaryan, I. I. Yakushchenko, and V. M. Beresnev, Uspekhi Khimii, 83, No. 11: 1027 (2014) (in Russian).

6. I. N. Maksimchuk, V. G. Tkachenko, A. S. Vovchok, N. P. Medalovich, and E. S. Makarenko, Metallofiz. Noveishie Tekhnol., 36, No. 1: 1 (2014) (in Russian).

7. S. A. Firstov, V. F. Gorban, N. A. Krapivka, E. P. Pechkovsky, and M. V. Karpets, Composites and Nanostructures, 7, No. 2: 72 (2015) (in Russian).

8. L. R. Shaginyan, V. F. Gorban, N. A. Krapivka, S. A. Firstov, and I. F. Kopylov, Superhard Materials, No. 1: 33 (2016) (in Russian).

9. S. A. Firstov, V. F. Gorban, N. A. Krapivka, N. I. Danilenko, and V. I. Kopylov, Mizhvuzivskii Zbirnyk 'Naukovi Notatky', Lutsk [Interuniversity Collection 'Scientific Notes', Lutsk], No. 54: 326 (2016) (in Ukrainian).

10. V. F. Gorban', N. A. Krapivka, and S. A. Firstov, Physics of Metals and Metallography, 118, No. 10: 970 (2017) (in Russian).

11. O. I. Yurkova, V. V. Cherniavsky, and O. I. Kravchenko, Metallofiz. Noveishie Tekhnol., 36, No. 4: 477 (2014) (in Russian).

12. D. G. Shaysultanov, Struktura i Mekhanicheskii Svoystva Vysokoentropiynykh Splavov Sistemy CoCrFeNiX ( $\mathrm{X}=\mathrm{Mn}, \mathrm{V}, \mathrm{Mn}, \mathrm{V}, \mathrm{Al}$ i Cu [Structure and Mechanical Properties of High-Entropy Alloys of the CoCrFeNiX System $(X=\mathrm{Mn}, \mathrm{V}, \mathrm{Mn}$ and $\mathrm{V}, \mathrm{Al}$, and $\mathrm{Cu})$ ] (Thesis of Disser. for the Degree of Technical sciences) (Belgorod: Federal State Autonomous Educational 
Institution of Higher Professional Education 'Belgorod State National Research University': 2015). (in Russian).

13. V. M. Yurov, S. A. Guchenko, and N. Kh. Ibraev, Mezhdunarodnyy Zhurnal Prikladnykh i Fundamentalnykah Issledovaniy [International Journal of Applied and Basic Research], No. 8: 148 (2010) (in Russian).

14. V. M. Yurov and V. S. Oleshko, Eurasian Physical Technical Journal, 16, No. 1 (31): 99 (2019).

15. G. Firstov, Yu. Koval, A. Timoshevskii, S. Yablonovskii, and J. Van Humbeeck, Chem. Met. Alloys, 6, 205 (2013) (in Ukrainian).

16. T. Kosorukova, G. Firstov, Y. Koval, P. Verhovlyuk, J. Van Humbeeck, and H. Noel, MATEC Web of Conferences, EDP Sciences, 33, 06005 (2015).

17. Diagrammy Sostoyaniya Dvoynykh Metallicheskikh Sistem: Spravochnik. [State Diagrams of Binary Metal Systems. Hand-book] (Ed. N. P. Lyakishev) (Moscow: Engineering: 1996-2000), vol. 1-3 (in Russian).

18. V. G. Pushin, N. N. Kuranova, N. I. Kourov, R. Z. Valiev, E. Z. Valiev, V. V. Makarov, A. V. Pushin, and A. N. Uksusnikov, Zhurnal Tekhnicheskoy Fiziki, 82, No. 8: 67 (2012) (in Russian).

19. K. S. Senkevich, Izv. Vuzov. Poroshkovaya Metallurgiya i Funktsionalnye Pokrytiya, No. 4: 71 (2017) (in Russian).

20. V. M. Yurov, Eurasian Physical Technical Journal, 8, No. 1 (15): 10 (2011) (in Russian). 